\title{
Changes in the structure and pigmentation of the eyes of honeybee (Apis mellifera L.) queens with the "limão" mutation
}

\author{
José Chaud-Netto and Carminda da Cruz-Landim
}

\begin{abstract}
This study describes the ultrastructural differences between the compound eyes of $\underline{\mathrm{ch}}^{\mathrm{li}} / \underline{\mathrm{ch}}^{\mathrm{li}}$ and $\underline{\mathrm{Ch}} / \underline{\mathrm{ch}}{ }^{\mathrm{li}}$ honeybee queens. Heterozygous "limão" bees had an almost normal ultrastructural organization of the ommatidia, but there were some alterations, including small vacuoles in the crystalline cones and a loss of pigment by primary pigmentary cells. In homozygous bees many ommatidia had very deformed crystalline cones and there were some bipartite rhabdoma. There was a reduction in the amount of pigment in the primary and secondary pigmentary cells and receptor cells (retinulae) of mutant eyes. However, the eyes of both heterozygous and homozygous queens had the same type of pigment granules. Certain membrane-limited structures containing pigment granules and electron-dense material appeared to be of lysosomal nature. Since these structures occurred in the retinular cells of mutant eyes, they were considered to be multivesicular bodies responsible for the reduction in rhabdom volume in the presence of light, as a type of adaptation to brightness. The reduction of pigment in the pigmentary and retinular cells and the morphological changes seen in the rhabdom of the ommatidia may originate visual deficiencies, which could explain the behavioral modifications reported for Apis mellifera queens with mutant eye color.
\end{abstract}

\section{INTRODUCTION}

Anatomical investigations of the compound eyes of insects reveal a regularity in the topographic disposition of the cellular elements. In all insects so far investigated, the ommatidium consists of a polygonal group of approximately eight receptors or retinula cells, with rhabdomeres extending toward the center of the polygons. In most insects, these rhabdomeres fuse into a variety of shapes to form a closed rhabdom, although some Diptera and Homoptera have open rhabdoma with a central cavity (Varela and Porter, 1969). The shape of the rhabdom is correlated with the way in which incoming light excites the receptors. Thus, in mosquito eyes, the rhabdom volume decreases upon illumination, a response which is probably mediated by a bleaching of the visual pigment, since blue light is most effective in producing this change whereas red light is least effective (Brammer and Clarin, 1976). The reduction in rhabdom volume apparently results from a loss of membrane to multivesicular bodies and coated vesicles.

Alterations in the normal pattern of eye organization or pigmentation may influence insect behavior. Morton and Cosens (1978) demonstrated that orientation responses of wild type red-eye and mutant brown and white-eye Drosophila melanogaster were different. These authors also noted that the accuracy of orientation and tropotatic responses were directly related to the extent of eye pigmentation.

In Apis mellifera, the flight activity of drones and queens with mutant eye color is frequently impaired since certain mutations in the "chartreuse" locus cause considerable difficulty in orientation (Witherell, 1971, 1972;
Chaud-Netto and Stort, 1980; Almeida, 1993, 1998). These mutations generally affect the amount and distribution of pigment in the eyes, especially in young bees (CruzLandim et al., 1979, 1980a) and, according to Tilson (1968), may lead to blindness in very luminous environments. This conclusion is based on the fact that drones with the darkest eye pigmentation have the highest rate of return to the hive after a flight (Witherell, 1972), and is also supported by the observation that chartreuse-red-eyed drones have less ommatidia than wild type black-eyed drones (Stort and Chaud-Netto, 1979). The ommatidia of the compound eyes of $\underline{\mathrm{Ch}} / \underline{\mathrm{ch}}^{\mathrm{r}}, \underline{\mathrm{ch}}^{\mathrm{r}} / \underline{\mathrm{ch}}^{\mathrm{r}}$ and wild type workers show certain ultrastructural differences, and degenerative alterations are more common in mutant bees (CruzLandim et al., 1980b).

Almeida (1993) found that $\underline{\mathrm{ch}} \underline{\mathrm{h}}^{\mathrm{li}} \underline{\mathrm{c}}^{\mathrm{li}}$ ("limão" or yellow-eyed) queens do not return to the hive after their first nuptial flight. In this study we examined the effect of the $\underline{\mathrm{ch}}^{\mathrm{li}}$ mutation on the morphology and ultrastructural organization of the compound eyes of $\underline{\mathrm{Ch}} / \underline{\mathrm{ch}}^{\mathrm{li}}$ and $\underline{\mathrm{ch}}^{\mathrm{li}} / \underline{\mathrm{ch}}^{\mathrm{li}}$ honeybee queens.

\section{MATERIAL AND METHODS}

The bees used in this study were newly emerged queens (one to three days old) of Africanized honeybees (Apis mellifera) with the genotypes $\underline{\mathrm{Ch}} / \underline{\mathrm{h}}^{\mathrm{li}}$ and $\underline{\mathrm{ch}}{ }^{\mathrm{li}} / \underline{\mathrm{ch}}^{\mathrm{li}}$, daughters of a queen heterozygous for the gene $\underline{\mathrm{ch}}^{\mathrm{li}}$ instrumentally mated to a "limão"-eyed drone. The queens were artificially inseminated (Camargo and Gonçalves, 1971). Ten queens $\underline{\mathrm{Ch}} / \underline{\mathrm{ch}}^{\mathrm{li}}$ and ten $\underline{\mathrm{ch}}{ }^{\mathrm{li}} / \underline{\mathrm{ch}}^{\mathrm{li}}$ were obtained as described by Doolittle (Johansson and Johansson, 1973). These bees were immobilized under cold tempera- 
ture $\left(4^{\circ} \mathrm{C}\right)$ and had their compound eyes separated from the head. The dorsal and lateral teguments of the heads, as well as the glands and air sacs around each optic lobe were removed to facilitate penetration of the fixing solution. The heads were then fixed in $3 \%$ glutaraldehyde in $0.2 \mathrm{M}$ cacodylate buffer, $\mathrm{pH} \mathrm{7.2,} \mathrm{for} 2 \mathrm{~h}$ at room temperature. Three samples from each queen were obtained from different eye regions. The optic lobes were cut into small fragments, rinsed in buffer, and post-fixed in $1 \%$ osmium tetroxide in the same buffer for $1 \mathrm{~h}$. The material was contrasted with ethanol uranyl acetate during early dehydration and embedded in epon-araldyte. Thin sections were stained with lead citrate and examined with a Zeiss EM9 S2 electron microscope (Cruz-Landim et al., 1980a).

\section{RESULTS AND DISCUSSION}

Transmission electron microscopy of the compound eyes of individuals heterozygous $\left(\mathrm{Ch} / \mathrm{ch}^{\mathrm{li}}\right)$ and homozygous ( $\underline{\mathrm{ch}}^{\mathrm{li}} \underline{\underline{\mathrm{ch}}}$ ) for the gene "limão" showed differences in the organization of the ommatidium and in the general pigmentation of the eye, which were similar to those of other bee eye mutants (Cruz-Landim et al., 1979, 1980a,b; Brammer and Clarin, 1976).

In heterozygotes the eye had a normal color and the ommatidia also had an almost normal ultrastructural organization. There were consistent alterations in the crystalline cone, including the presence of small vacuoles in the cone cells and a certain loss of pigment by the pri-

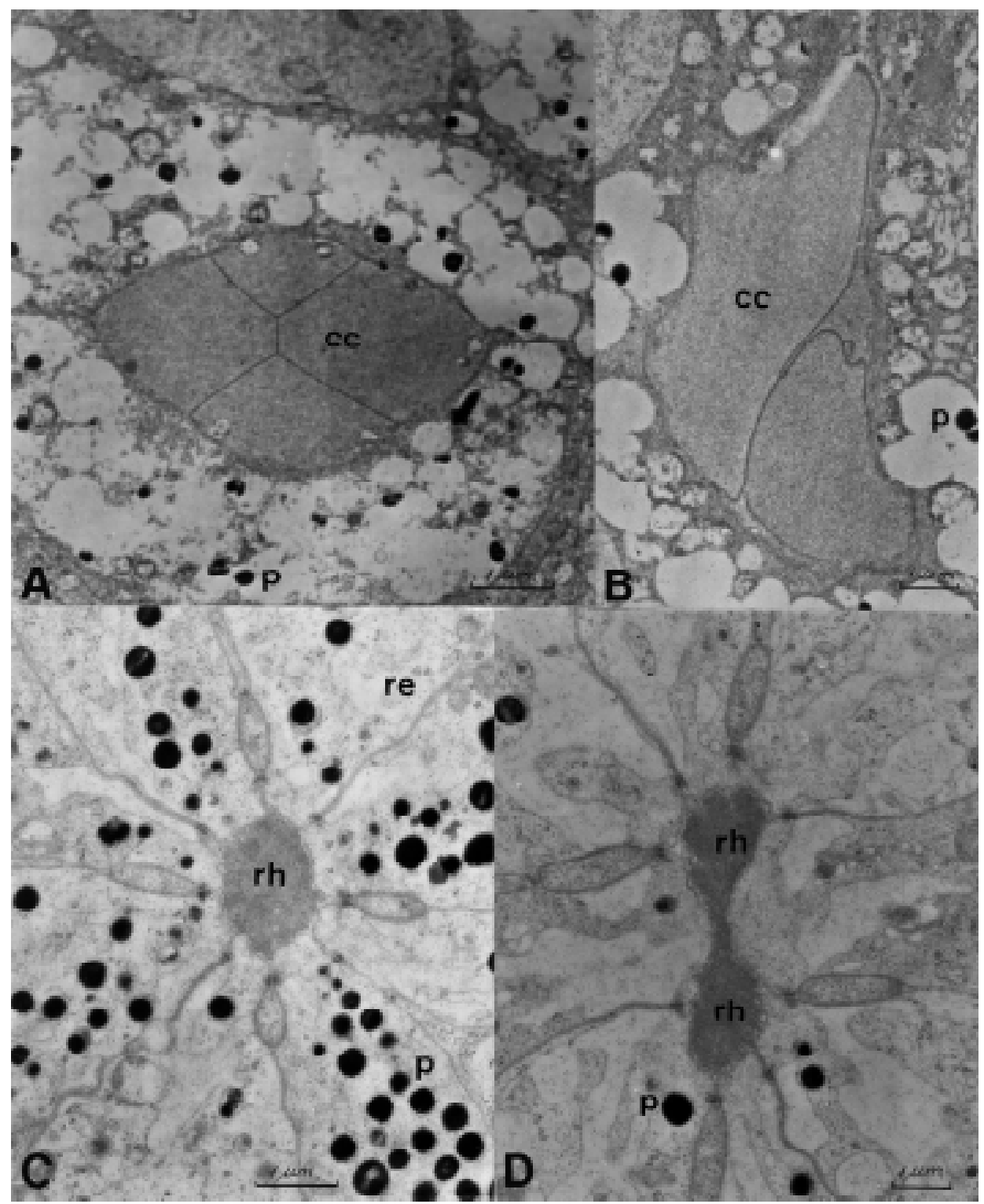

Figure 1 - Transmission electron micrographs of an ommatidium in the crystalline cone (cc) region. A, Normal aspect found in heterozygous queens. $\mathbf{B}$, Deformed crystalline cone found in mutant $\left(\underline{\mathrm{ch}}^{\mathrm{li}} / \underline{\mathrm{ch}}^{\mathrm{li}}\right)$ queens. Note the poor pigmentation (p) in both cases. C, D, Cross-section in a retinal (re) region. C, The normal appearance of a heterozygous retina (re). D, The bipartite rhabdom (rh) in a mutant. Note the differences in pigmentation. 


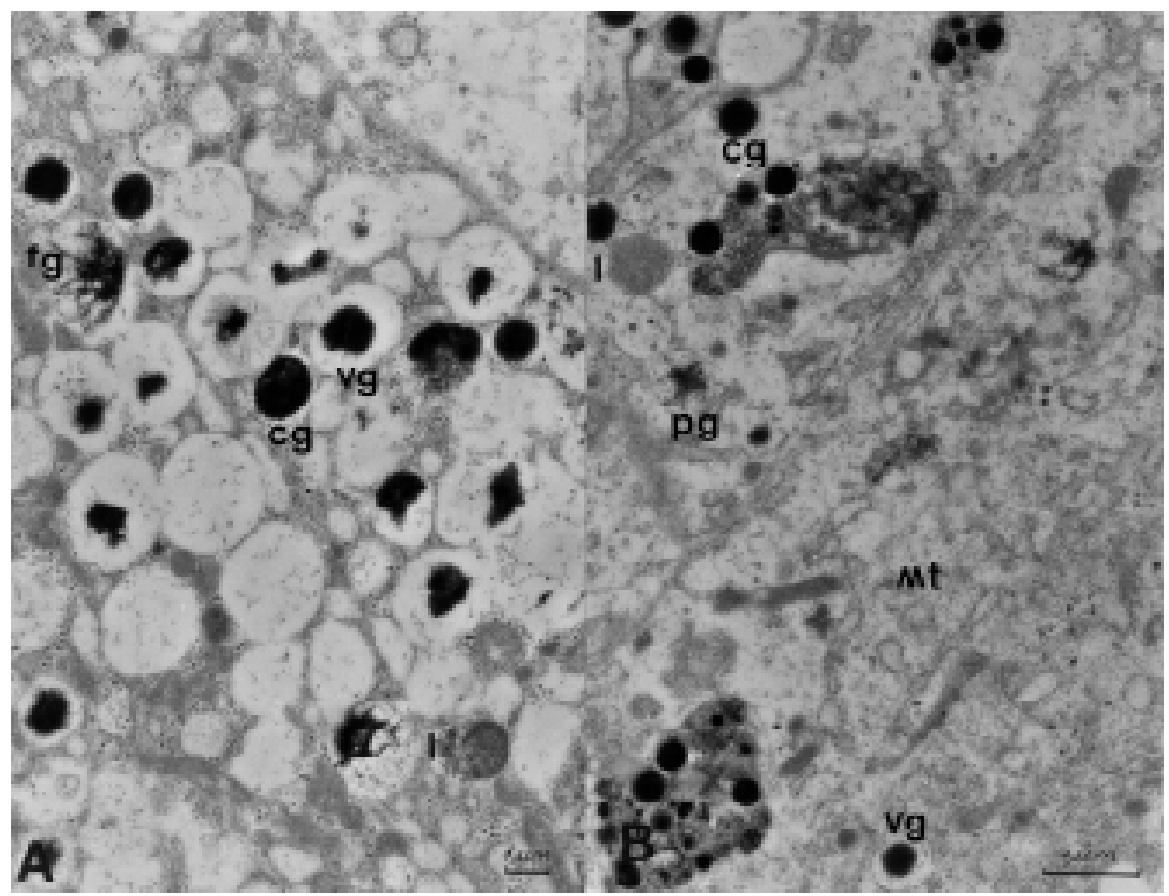

Figure 2 - Types of pigment granules (p). A, Heterozygote. B, Mutant. fg, Fibrous granule; cg, compact granule; vg, vesicular granule; pg, polymorphous granule. Note the presence of lysosomal structures (l) and microtubules (mt).

mary pigmentary cells (Figure 1A). These changes were observed in all heterozygous queens examined. The other parts of the ommatidium were normal (Figure 1C).

In the mutants (homozygotes) several ommatidia had very deformed crystalline cones (Figure 1B). The rhabdom of some ommatidia also appeared bipartite (Figure 1D). However, it was not possible to determine whether the ommatidia with deformed crystalline cones were from retinas with bipartite rhabdoma.

There was a reduction in the amount of pigment in the pigmentary (primary and secondary) and receptor (retinulae) cells of mutant eyes, although the type of pigment granules present was the same in both cases, in contrast to the situation reported for the genes "chartreuse" and "laranja" (Cruz-Landim et al., 1980a). In the present case, only the amount of pigment changed with the mutation (Figure 2A,B). The membranous structures containing pigment granules and an electron-dense ground material appeared to be of a lysosomal nature. These structures were present in the retinular cells of all mutants examined (Figure $2 \mathrm{~B}$ ) and corresponded to the multivesicular bodies responsible for the reduction in rhabdom volume in the presence of light (Brammer and Clarin, 1976). Since mutant eyes have less pigment in the pigmentary and retinular cells, the increase in incident light at the rhabdom could lead to a reduction in the number of rhabdomere microvilli as a mechanism of adaptation to brightness.

Controlling the incidence of light on the rhabdom is of crucial importance in the physiology of insect vision (Bernard et al., 1984). Most of this control is achieved by moving pigment granules present in these cells in response to the degree of illumination. This movement is via a network of microtubules within the cells (Figure 2B).

The reduction of pigment in the pigmentary and retinular cells and the morphological changes seen in the rhabdom of the ommatidia may originate visual deficiencies which could explain the behavioral modifications reported by Morton and by Cosens (1978) for Drosophila and by Almeida (1998) for Apis mellifera queens. Although eye color in heterozygous bees is frequently the same as in wild type individuals, there are small differences in the amount of pigment. However, such differences do not seem to impair visual acuity since no behavioral alterations have been reported in queens heterozygous for the genes cream, "laranja" and brick (Almeida, 1998).

\section{ACKNOWLEDGMENTS}

Publication supported by FAPESP.

\section{RESUMO}

Este estudo descreve as diferenças ultra-estruturais entre os olhos compostos de rainhas de abelhas de genótipo $\underline{\mathrm{ch}}^{\mathrm{li}} / \underline{\mathrm{ch}}^{\mathrm{li}} \mathrm{e}$ $\underline{\mathrm{Ch}} / \underline{\mathrm{ch}}^{\mathrm{li}}$. Foram registradas diferenças na organização do omatídeo e na pigmentação geral dos dois tipos de olhos. As abelhas heterozigotas apresentaram organização ultra-estrutural dos omatídeos praticamente normal. Contudo, foram observadas algumas alterações nos cones cristalinos, particularmente a presença de pequenos vacúolos nas células dos cones e perda de pigmento pelas células pigmentares primárias. Nas abelhas 
homozigotas foram encontrados vários omatídeos com cones cristalinos muito deformados e alguns omatídeos com rabdoma bipartido. A quantidade de pigmento nas células pigmentares primárias e secundárias, bem como nas células receptoras (retinulares) do olho mutante, foi menor. Contudo, os olhos das rainhas heterozigotas e homozigotas apresentaram o mesmo tipo de grânulos de pigmento. Estruturas limitadas por membranas contendo grânulos de pigmento e material eletro-denso, aparentemente de natureza lisossomal, também foram observadas. Como elas foram vistas nas células retinulares dos olhos mutantes, foram interpretadas como corpos multivesiculares responsáveis pela redução do rabdoma, sob a presença de luz. A redução de pigmento nas células pigmentares e retinulares e as alterações morfológicas observadas no rabdoma dos omatídeos podem dar origem a deficiências visuais, que poderiam explicar as modificações comportamentais relatadas para rainhas de Apis mellifera mutantes para a cor dos olhos.

\section{REFERENCES}

Almeida, R. (1993). Estudo de alguns parâmetros comportamentais e morfológicos em abelhas mutantes, chartreuse-limão (Apis mellifera). Master's thesis, Faculdade de Medicina, Universidade de São Paulo, Ribeirão Preto, SP.

Almeida, R. (1998). Estudo de alguns parâmetros comportamentais em abelhas mutantes para cor dos olhos e técnicas de estocagem de sêmen. Doctoral thesis, Faculdade de Medicina, Universidade de São Paulo, Ribeirão Preto.

Bernard, G.D., Owens, E.D. and Harley, A.V. (1984). Intracellular optical physiology of the eye of the pyralid moth Amyelois. J. Exp. Zool. 229: 173-187.

Brammer, J.D. and Clarin, B. (1976). Changes in volume of the rhabdom in the compound eye of Aedes aegypti L. J. Exp. Zool. 195: 33-39.

Camargo, J.M.F. and Gonçalves, L.S. (1971). Manipulation procedures in the technique of instrumental insemination of the queen honeybee Apis mellifera L. (Hymenoptera: Apidae). Apidologie 2: 239-246.

Chaud-Netto, J. and Stort, A.C. (1980). Successful matings of chartreuseeyed queens of Apis mellifera (Hymenoptera, Apidae). Ciênc. Cult. 32: $1542-1543$.

Cruz-Landim, C., Chaud-Netto, J. and Gonçalves, L.S. (1979). Morphological alterations in the compound eyes of eye-color mutants of Apis mellifera L. (Hymenoptera, Apidae). I. Rev. Bras. Genét. II: 223-231.

Cruz-Landim, C., Chaud-Netto, J. and Gonçalves, L.S. (1980a). Comparative studies on pigment granules and pigment distribution in the compound eyes of wild type and mutant worker honeybees: an ultrastructural analysis. II. Rev. Bras. Genét. III: 115-122.

Cruz-Landim, C., Chaud-Netto, J. and Gonçalves, L.S. (1980b). Alterations in the ommatidia of the compound eyes of Apis mellifera eye-color mutant workers. III. Rev. Bras. Genét. III: 123-126.

Johansson, T.S.K. and Johansson, M.P. (1973). Methods for rearing queens. Bee World 54: 149-175.

Morton, P.D. and Cosens, D. (1978). Vision in Drosophila: evidence for the involvement of retinula cells 1-6 in the orientation behaviour of Drosophila melanogaster. Physiol. Entomol. 3: 323-334.

Stort, A.C. and Chaud-Netto, J. (1979). Estruturas sensoriais e atividade de vôo em abelhas africanizadas (Apis mellifera adansonii). Rev. Bras. Biol. 40: 717-720.

Tilson, K.L. (1968). Electrophysiological responses in mutant eyed drones (Apis mellifera) to selected wavelengths of light. Master's thesis, University of California, Davis, CA.

Varela, F.G. and Porter, K.R. (1969). Fine structure of the visual system of the honeybee. I. The retina. J. Ultrastruct. Res. 29: 236-259.

Witherell, P.C. (1971). Duration of flight and interflight time of drone bees, Apis mellifera. Ann. Ent. Soc. Am. 64: 609-612.

Witherell, P.C. (1972). Flight activity and natural mortality of normal and mutant drone honeybees. J. Apic. Res. 11: 65-75.

(Received November 26, 1998) 